\title{
Effect of Foot Massage on Decreasing Blood Pressure in Hypertension Patients in Bontomarannu Health Center
}

\author{
Fitriani $^{1}{ }^{*}$, Risnawati HR ${ }^{1}$, Ratnasari' ${ }^{1}$ Maria Ulfah Azhar ${ }^{1}$ \\ ${ }^{1}$ Nursing Department Faculty of Medicine and Health Sciences, Alauddin Islamic State University \\ fitrianinuma@gmail.com \\ DOI: http://doi.org/10.29080/jhsp.v3i3S.304
}

\section{Keywords}

Foot Massage;

Blood Pressure;

Hypertension

\begin{abstract}
Hypertension is called the silent killer because the symptoms are often without complaints. The number of people with hypertension in the world continue to increase every year, estimated that by 2025 there will be 1.5 billion people affected by hypertension. It is also estimated that every year 9.4 million people die from hypertension and complications. when anti-hypertension is needed, nonpharmacological treatment can be used as a complement to get a better treatment effect. One of the non-pharmacological therapies offered to reduce hypertension with massage therapy (massage). The aim of the study was to determine the effect of foot massage on reducing blood pressure in hypertensive patients in the work area of Bontomarannu Health Center, Gowa Regency. This research was conducted on January 2015 using the static group comparison method. The population in this study were residents in the working area of Bontomarannu Health Center and samples were taken with purposive sampling technique with a total sample of 20 people. Based on the results of the study it was found that the administration of foot massage interventions can reduce blood pressure. The statistical test results showed between the systole control group ( $p$-value 0.798$)$, the diastolic control group ( $p$-value 0.726 ) and the systolic treatment group (p-value 0.004), the diastolic treatment group (p-value 0.005 ). The administration of foot massage intervention has an influence on the decrease in blood pressure compared to the group that is not given a foot massage intervention.
\end{abstract}

\section{Introduction}

Hypertension is called the silent killer because the symptoms are often without complaints. Usually, sufferers do not know that they have hypertension and are only known after complications occur. Hypertension is the most common cause of cardiovascular events and is a major problem in developed and developing countries. Cardiovascular is also the number one cause of death in the world every year (1).

According to WHO Data 2015 shows that around 1.13 billion people in the world suffer from hypertension. That 1 in 3 people in the world are diagnosed with hypertension, only $36.8 \%$ of them take medication. The number of people with hypertension in the world continues to increase every year, estimated in 2025 there will be 1.5 billion people affected by hypertension. It is also estimated that every year 9.4 million people die from hypertension and complications (1).

In Indonesia, based on the 2013 Riskesdas, the prevalence of hypertension in Indonesia was 25.8\%, the highest prevalence occurred in Bangka Belitung $(30, \%)$ and the lowest in Papua $(16.8 \%)$. Meanwhile, the 2016 National Health Indicator Survey (Sirkesnas) data showed an increase in the prevalence of hypertension in people aged 18 years and over by 32.4\%. In addition, according to BPJS Health data, the cost of hypertension services has increased every year, namely Rp. 2.8 trillion in 2014, Rp. 3.8 trillion in 2015, and Rp. 4.2 trillion in 2016 (1).

The prevalence of hypertension in older adults of 30 increased from $22.3 \%$ to $24.6 \%$ in 2007 and to $26.9 \%$ in 2008 , with men having a higher prevalence than women (29.4\% compared to $26.4 \%$ of women). The prevalence of hypertension was $23.4 \%$ overall and also higher in men $(28.4 \%$ compared to $18.7 \%$ of women), with a significant increase prevalence starting in 40 years old (1). Based on the profile of the South Sulawesi provincial health office in 2008, hypertension was ranked first with the number of cases 
reaching 63.66\% while in 2009 the number of cases reached 49.56\%. In 2012, hypertension was ranked second after asthma for the biggest cause of death in the city of Makassar and Gowa Regency with a total of 574 people due to hypertension (2).

However, hypertension still has not received enough attention. The main cause of this disease is only showing symptoms after advanced. This causes the treatment of hypertension has not achieved satisfactory results, for example in the United States the success of this therapy until 1994 was only about $30 \%$ (Sheps, 2005). Handling of hypertension can be done by pharmacological means, namely with antihypertensive drugs or non-pharmacological, namely by lifestyle modification or it can be a combination of both (3).

On when this is anti-hypertension necessary, non-pharmacological treatment could used as complementary for get effect more treatment good (1). Some research has been prove that nonpharmacological treatment is intervention required to be do on every treatment hypertension (4). Wrong one non-pharmacological therapy offered for bring down hypertension with therapy massage (massage). Technique massage could eliminate blockage in Flow blood so that Flow blood and energy in in body back smoothly (5).

On case hypertension therapy massage through point acupuncture strengthen back energy body and body already weak. Acupuncture this work based on meridian theory namely qi (vital energy) and Circulating blood in body through system channels called meridians that connect the internal organs with external. With massage, period certain on surface body located dijalur meridians are stimulated so that Flow qi and blood can arranged so that the risk disease hypertension and the complication could minimized (5).

According to research conducted by Sari, et al, currently treatment for treating hypertension is done in various ways, one way to treat hypertension is by massage. Massage techniques affect the smooth circulation of blood, balance the flow of energy in the body and relax muscle tension. Although researchers consider massage techniques will not have much impact on severe hypertension, some studies have shown that massage can reduce blood pressure in patients with mild and moderate hypertension (6).

Based on preliminary data from Gowa District Health Center Bontomarannu in 2013 in the number of visits (outpatient) in Bontomarannu Subdistrict, hypertensive patients had 178 cases of hypertension, the number of men was 82 people and women were 96 people. In 2014 hypertension patients reached 259 cases of hypertension, the number of men was 117 people and women were 142 people. From the preliminary data obtained while it can be seen that patients with hypertension cases are more dominated by women (7).

\section{Method}

Research was held on January 2015 using the static group comparasion. The population in this study were residents in the working area of Bontomarannu Health Center and samples were taken with purposive sampling technique with a total sample of 20 people .

The instrument used in collecting data is by using interview techniques and observing measurements through the observation sheet. The technique of direct interviews with respondents was conducted to examine demographic data such as name, age, type sex and others. Meanwhile, observation measurements were made to get the respondent's blood pressure.

\section{Result}

Table 1 Respondent Frequency Distribution Based on Demographic Data

\begin{tabular}{cccc}
\hline \multicolumn{2}{c}{ Biographic Data } & $\mathrm{n}$ & Percentase (\%) \\
\hline Age & $40-48$ years & 8 & 40 \\
& $49-57$ years & 6 & 30 \\
Religion & $58-65$ years & 6 & 30 \\
& Islam & 20 & 100 \\
& Christian & - & - \\
Tribe & Hindu & - & - \\
& Buddha & - & 100 \\
& Makassar & 20 & - \\
Work & Bugis & - & - \\
& There is & - & 100 \\
\hline
\end{tabular}

Source: primary data, 2015 
Based on table 1, it can be seen that the distribution of respondents based on the highest age was 40-48 years old as many as 8 respondents (40\%). In the distribution of respondents based on the most religions, there were 20 respondents of Islam (100\%). in the distribution of respondents based on the most ethnic groups, there were 20 respondents who were Makassar (100\%). on the distribution of respondents based on the highest number of jobs were 20 respondents who did not work (100\%).

Table 2 Paired T-Test Test Results in the Control Group (pre-post test systole)

\begin{tabular}{ccccc}
\hline & Average $(\mathrm{sb})$ & Difference $(\mathrm{sb})$ & $95 \%$ IK & P value \\
\hline $\begin{array}{c}\text { Blood pressure } \\
\text { before foot } \\
\text { massage }\end{array}$ & $134.00(10.75)$ & $0.70(8.39)$ & $5,30-6,70$ & $\begin{array}{c}\text { Systole: } 0.798 \\
\text { Diastol: }-\end{array}$ \\
$\begin{array}{c}\text { Blood pressure } \\
\text { after foot } \\
\text { massage }\end{array}$ & $134.70(11.03)$ & & \\
\hline Paired t test; difference between after and before & &
\end{tabular}

in table 2 a paired T-test was carried out because in the normality test only the pre and post systole control groups were normally distributed. After the T-Paired Test was conducted the p-value in the control group (pre-post test systole) was 0.798 or $p>0.05$, meaning there was no effect of the control group on blood pressure reduction.

Table 3 Wilcoxon Test Test results in the treatment group (pre-post test systole and pre-post test diastole) and in the control group (pre-post diastole)

\begin{tabular}{ccc}
\hline & Median & P value \\
\hline Group blood pressure treatment & Systole: $133(130-160)$ & \\
before foot massage & Diastol: $92(90-100)$ & Systole: 0.004 \\
Blood pressure group treated after & Systole: $110(110-130)$ & Diastol: 0.005 \\
foot massage & Diastol: $79(74-82)$ & \\
Blood pressure control group & Pre test diastolic test: $83(80-$ & Diastol: 0.726 \\
& 100) & \\
\hline
\end{tabular}

In table 3 After the Wilcoxon signed ranks test was performed the $p$-value in the treatment group (pre-post systole) was 0.004 or $\mathrm{p}<0.05$, the treatment group (pre-post diastole) was 0.005 or $\mathrm{p}<0.05$, meaning there was a variable influence (treatment group) on decrease in blood pressure in people with hypertension. Whereas in the control group (pre-post diastole) of 0.726 or $p>0.05$ it means that there is no variable influence on the decrease in blood pressure. It can be concluded that after the Wilcoxon test, it can be seen that foot massage influences the decrease in blood pressure seen from the p-value in systolic blood pressure 0.004 and blood pressure at the level of 0.005 which means $\mathrm{p}<0.05$.

\section{Discussion}

Blood pressure is regulated by a series of autonomic nerves and hormones that monitor blood volume in circulation, blood vessel diameter, and heart contraction. Each of these factors is intrinsically closely related to regulation of blood pressure in the blood vessels.

The value of blood vessels depends on the strength of the contraction of the heart, the diameter of the blood vessels, and the volume of blood in the circulation. The mechanism works similar to the pressure of water coming out of the hose. You can increase the strength of the water by turning the cramp water larger (the same as making the heart contract stronger and faster) or by pressing the end of the hose and increasing the pressure of the hose (same as the blood vessels that narrow and contract).

Massage or massage is the use of various pressures and movements to manipulate muscles and other soft tissues. By relaxing the soft tissues of the body, more blood and oxygen can reach the affected area and reduce pain. Massage is a sensory integration technique that affects the activity of the autonomic nervous system. If someone perceives touch as a relaxed stimulus, a relaxation response will emerge.

Based on the results of the study showed that all respondents in the control group did not experience a decrease in blood pressure and in the treatment group experienced a decrease in blood pressure. This happened because in the control group no intervention was given where only two measurements were taken, namely the first measurement and the second measurement after 20 minutes later. No reduction in blood pressure in the control group was also affected because there were some respondents who still consumed food such as meatballs, fried foods, etc. that could increase blood pressure and there were also respondents who had family problems so that respondents became stressed as a result when the measurements did not occur the decrease even increased when the second measurement was 
made. Meanwhile, in the treatment group there was a decrease in blood pressure because the intervention was given, namely giving foot massage.

After the Wilcoxon test was tested the $p$-value in the treatment group (pre-post systole) was 0.004 or $\mathrm{p}<0.05$, the treatment group (pre-post diastole) was 0.005 or $\mathrm{p}<0.05$ means that there was a variable influence (treatment group) on pressure drop blood in hypertensive patients. Whereas in the control group (pre-post diastole) of 0.726 or $p>0.05$ it means that there is no effect of the control group on the decrease in blood pressure. It can be concluded that after the Wilcoxon test, it can be seen that foot massage influences the decrease in blood pressure seen from the p-value in systolic blood pressure 0.004 and blood pressure at the level of 0.005 which means $\mathrm{p}<0.05$.

This is in accordance with the research conducted by Sari, et al in 2009 entitled the effect of foot massage on blood pressure reduction. With the clinical trial method the pre-experimental method with the study design using a pretest-posttest design. The population used was women with prehypertension. The sample in the study amounted to 10 people. Prehypertension sufferers were selected by purposive sampling. Sampling by purposive sampling is done for certain purposes. This type of sampling is included in nonprobality sampling where this sampling technique does not provide equal opportunities for each member of the population, which aims not to generalize, which is based on unequal probabilities. The instruments used were mercury sphygmomanometer blood pressure measuring instruments, stethoscopes and documentation sheets to record the blood pressure of the respondents. The results showed that before foot massage, women with prehypertension with an average blood pressure value of 133/83 mmHg. After massage, blood pressure drops to normal with an average value of $120 / 75 \mathrm{mmHg}$. There is a significant difference with the foot massage against prehypertension female blood pressure $(6,8)$.

According to research conducted by Radar (2009) in PKU Muhammadiyah General Hospital Malang, foot massage was used in a person suffering from hypertension, his systolic blood pressure before treatment was $180 \mathrm{mmHg}$ after therapy for 30 minutes, his systolic blood pressure decreased $150 \mathrm{mmHg}$. This decrease in systolic blood pressure is because foot massage can relax the body and blood vessels undergo vasodilation.

The results showed that foot massage is a very effective therapy. Massage your feet both to relax the muscles, reduce pain, improve body organs, improve posture, and as a passive exercise (4). The decrease in blood pressure is caused by sensory integration techniques that affect the activity of the autonomic nervous system, if someone perceives touch as a relaxed stimulus a relaxation response will emerge.

Movement of foot massage consists of motion effleurage, massage on the feet, effleurage. This movement is continuous or the flow is unbroken so that energy flows from one meridian to the other meridians in a regular order (9). Therefore, massage by hand must not be lifted at all because it will decide the flow of massage as a whole, hands must always touch the body in all the back and forth movements carried out in sequence.

In principle, massage performed on hypertensive patients is to facilitate the flow of energy in the body so that hypertensive disorders and their complications can be minimized. When all energy pathways are open and the energy flow is no longer blocked by muscle tension and other obstacles, the risk of hypertension can be reduced (5).

Some research results show that foot massage is good for lowering blood pressure. Based on the results of the observation sheet that the respondents who were given foot massage intervention all experienced a decrease in blood pressure while in the group not given the intervention almost all respondents did not experience a decrease even some respondents experienced an increase in blood pressure after blood pressure measurements were taken. The results of this study can also be used as a source of information and referral to conduct further research related to research that researchers have done specifically in the field of academics while for health centers, especially nurses can make it as one of the nurse's independent interventions to reduce blood pressure in patients with hypertension.

\section{Conclusion and Sugestion}

Intervention of foot massage for patients with hypertension is effective against a decrease in blood pressure from mild to moderate. Giving foot massage in patients with hypertension is one of the non-pharmacological therapies to reduce blood pressure. But it is necessary to conduct a similar study or with other types of non-pharmacological therapy with more respondents to get better results using pure experimental methods. For the next researchers, it is highly recommended to involve more participants and the time of research should be extended to avoid bias. The author expresses his gratitude to the people for participated in this study, lecturers, classmates for helped in collecting data, and Bontomarannu health centers.

\section{References}


1. Ministry of Health. Killing Hypertension Secretly, Know Your Blood Pressure.

2. Profil of Health Department South Sulawesi. 2012.

3. Dekker E. Living with High Blood Pressure. Jakarta: CV. Mulia Sari; 1996.

4. Safitri P. Effectiveness of Foot Massage with Lavender Essential Oil to Decrease Blood Pressure in Hypertension Patients at Buntu Bedimbar Village, Tanjung Morawa Subdistrict, Deli Serdang Regency. Univ. North Sumatra; 2012.

5. Setiawan Dalimartha. Care Your Self; Hypertension. Jakarta: Spreader Plus; 2008.

6. Sari T, Alleen. Differences in Blood Pressure before and After Foot Massage using Lavender Essential Oil against pre hypertension Women in Karyawangi Village, West Bandung Regency. 2014.

7. The Data of Bontomarannu Health Center. 2014;

8. Smeltzer, Bare. Textbook for Medical Surgical Nursing. Jakarta: EGC; 2001. (8).

9. Thie J. Touch for Health; Practical Instructions for Natural Health with a Touch of Acupressure. Jakarta: Grasindo; 2007. 